\title{
ПРОБЛЕМА ЗНАЧЕННЯ МОВНИХ ОДИНИЦЬ У СУЧАСНІЙ ЛІНГВІСТИЧНІЙ ПАРАДИГМІ
}

\begin{abstract}
Леута О. І. Проблема значення мовних одиниць у сучасній лінгвістичній парадигмі.

Статтю присвячено проблематиці значення у лінгвістичних дослідженнях, його філософському та логічному потлумаченню. Головну увагу зосереджено на питаннях значення одиниць лексико-семантичного рівня, їхньої специфіки та варіантів реалізації. Простежено взаємозв'язок між значенням слова та речення, акцентовано на пріоритеті значення речення.

Ключові слова: значення, комунікація, речення, референція, семантика, слово, функція.
\end{abstract}

Леута А. И. Проблема значения языковых единиц в современной лингвистической парадигме.

Статья посвящена проблематике значения в лингвистических исследованиях, его философскому и логическому толкованию. Главное внимание сосредоточено на вопросах значения единиц лексико-семантического уровня, их специфики и вариантов реализации. Рассмотрена взаимосвязь между значением слова и предложения, акцентировано на приоритете значения предложения.

Ключевые слова: значение, коммуникация, предложение, референция, семантика, слово, функция.

Leuta O. I. The problem of language units' meaning in modern linguistic paradigm.

The article is devoted to the problems of meaning in linguistic studies, its philosophical and logical interpretation. The main focus is on the issues of meaning on lexical and semantic levels, and their specific realization. The relationship between the word's and the sentence's meaning are analyzed with accent on the priority of sentence's meaning.

Key words: meaning, communication, sentence, reference, semantics, word, function.

Питання аналізу мовного значення належить до гносеологічних проблем, але попри давню наукову традицію й актуальність не має сьогодні навіть перспективи вирішення. Їі складність полягає в тому, що вона безпосередньо пов'язана $з$ онтологічними питаннями самої природи людської мови, сутністю процесу відображення мовними засобами навколишнього світу. Саме тому над розв'язанням цього важливого питання працює не лише лінгвістика, але й не меншою мірою логіка, філософія, інші гуманітарні науки. Важливим при цьому є те, що «..якщо лінгвістичний інтерес до проблеми полягає в розкритті сутності значення як інгредієнта мовної структури, то для філософії проблема має більшу ๑ О. О. І. Леута, 2015. 
значущість: вона виходить за межі власне лінгвістичні, охоплює сферу співвідношення світу речей, світу мови і світу ідей» [1, с. 3].

Водночас, попри важливість інтеграції гуманітарних досліджень багато лінгвістів досі вважає цю проблему суто мовознавчою. В. Звєгінцев наголошує на тому, що «проблема мовного значення $\epsilon$ лінгвістичною проблемою, до того ж найважливішою 3 лінгвістичних проблем. I лінгвісти не мають права передоручати їі іншим наукам, вони самі повинні ії вирішити» [5, с. 39].

Сам термін «значення» в мовознавчих дослідженнях започаткували ще представники грецької граматичної школи, пізніше він став одним із найпоширеніших у працях науковців різних лінгвістичних шкіл і напрямів. У наукових розвідках зустрічаємо широкий діапазон термінопозначень цього складного поняття: лексичне, семантичне, синтаксичне, граматичне, стилістичне, конкретне, абстрактне, категорійне, дериваційне, конотативне, комунікативне та ін. Таку диференціацію й обшир семантики можна пояснити тим, що значення є об'єктом дослідження різноманітних розділів і напрямів мовознавчої науки з власною методикою, метамовою, а також низки інтерлінгвістичних дисциплін: етнолінгвістики, психолінгвістики, лінгвокультурології, семіотики.

Значення в мові з погляду філософії є лінгвістичним вираженням відношення людської думки, свідомості до навколишньої дійсності, яке виявляється у різноманітних комунікативних актах. Це мовна форма діяльності думки в сукупному контексті дій суб'єкта, що спрямована на задоволення його соціальних потреб і на досягнення певної мети. Пізнати явище - це означає виразити його мовними засобами. При цьому важливо пам'ятати те, що дійсність відображає не мова, а мислення, мова ж лише інтерпретує іiі. Тому приписувати мові те, що характерно для мислення це ототожнювати мову з мисленням.

Факт різнопланового багатогранного використання мови свідчить про те, що значення у мові зумовлене не лише позамовною дійсністю і внутрішньосистемними мовними відношеннями, але й цілеспрямованою діяльністю суб'єкта, який використовує мову для досягнення певної мети. Хоча мовленнєва діяльність людини як невід'ємна частина людської діяльності загалом об'єктивно зумовлена, вона визначена також прагматичною співмірністю суб'єкта із зовнішніми предметами чи явищами. Людський фактор у взаємовідношеннях людини і світу виступає одним із важливих конституентів значення в мові, а значення, відповідно, $\epsilon$ засобом організації різноманітних форм людської діяльності.

У логічній семантиці значення розуміють як «...об'єкт, що зіставлений 
у процесі інтерпретації певної природної чи штучної мови з будь-яким його вираженням в імені. Таким об'єктом може бути як річ у собі, так і думка про річ. Тому в логічній семантиці розрізняють два основні види значення: екстенсіальне (предмет чи клас предметів, що позначений цим висловленням) і інтенсіальне (зміст вираження)» [6, с. 162]. Категорія значення найчастіше виражена у логічній семантиці набором опозицій, які мають різну номінацію в окремих дослідників: значення $i$ зміст у Г. Фреге; екстенсіонал і інтенсіонал у Р. Карнапа; референція $i$ значення в У. Куайна; денотат і сигніфікат у А. Черча, назване $i$ значення у Д. Мілля.

Розглядаючи проблему значення в мові, варто звернути увагу на розмежування значення одиниць різних рівнів. Особливу увагу в розгляді проблеми значення сучасні дослідники надають значенню слова як особливої знакової одиниці, бо в ньому найповніше відображено і збережено соціально-історичний досвід носіїв кожної мови. Окрім того, найчастіше значення мовного знака пов'язане зі словом тому, що воно (слово) є двосторонньою одиницею, у якій зв'язок значення і звучання чи графічного оформлення зумовлений суспільними, історичними й психологічними чинниками. За такого розуміння слова як основної номінативної одиниці його значення можна визначити як «відоме відображення предмета, явища чи відношення у свідомості, що входить до структури слова як внутрішня іiї сторона, стосовно якої звучання слова виступає матеріальною оболонкою, необхідною не лише для вираження значення і повідомлення його іншим людям, але й для самої його появи, формування, існування і розвитку» [7, с. 89].

У дослідженні лексичної семантики дуже важливим є з'ясування значеннєвої структури слова, що, за словами В. Виноградова, представляє «внутрішню конструктивну єдність лексичних і граматичних значень» [3, с. 15] і значною мірою зумовлена граматичною будовою кожної мови. На думку багатьох учених, у флективних мовах синтетичного типу слово поєднує значення граматичних категорій і лексичного наповнення, тобто морфологічно $\epsilon$ більш насиченим, а лексично вужчим, спеціалізованим.

Тривала і досить плідна практика дослідження слова уможливила чітке розмежування лексичного і граматичного значень, морфологічну і семантичну структуру слова, що відображено у протиставленні термінів «граматичне і фонологічне слово» [2].

Тісний зв'язок і разом з тим диспропорцію між обсягом лексичного i граматичного у слові можна пояснити невідповідністю між конструктивними можливостями мови i величезним обсягом та різнорідністю інформації, що виражена цими засобами. Суспільне життя ○ О. І. Леута, 2015. 
на сучасному етапі у зв'язку 3 перенасиченістю інформацією та обмеженістю мовних ресурсів постійно ставить перед мовними системами нові й нові завдання. Мова в нових умовах повинна адаптуватися, відкривати все нові внутрішні можливості використання уже наявних засобів, розширювати та модифікувати їх.

У зв'язку з цим багато дослідників пов'язують онтологію значення не зі словом, а 3 одиницею вищого порядку - реченням. Розуміння значення речення нетотожне розумінню значення слова. Речення виражає мовними формами спрямованість думки на той чи той предмет i прагнення людського розуму розкрити потрібну йому сторону речі, репрезентує зацікавлення суб'єкта в певному практично вагомому аспекті пізнання реалій дійсності. Значення речення $\epsilon$ мовним утіленням цілеспрямованого руху нашої думки до об'єкта, тому можна вважати, що відправним пунктом в аналізі значення у мові доцільніше вважати значення речення, а не значення слова.

Проблема теорії речення на сьогодні є надзвичайно актуальною. На думку I. Вихованця, «центральне питання синтаксису мови - дати викінчену теорію речення як основної синтаксичної одиниці, оскільки основна синтаксична одиниця включає до своєї структури інші синтаксичні одиниці, нижчі за граматичним рангом і підпорядковані їй» [4, с. 48]. 3 огляду на це деякі дослідники взагалі ігнорують пізнавальну роль слова і зводять її лише до функційної. Дж. Черч говорить: «Слова не мають значень, вони мають функції. Значення, що закріплені за словами у словниках, є абстракціями від способів їхнього застосування» [10, с. 127].

Пріоритет значення речення над значенням слова чи словосполучення очевидний, однак зовсім не нівелює пізнавальної ролі лексичного значення і не означає зведення ролі значень слів лише до їхніх функцій у реченні чи відірваність значення від зовнішнього світу, бо тільки через значення мова наповнена справжнім об'єктивно-реальним змістом. Лексичне значення $є$ «вікном» у навколишній світ. Завдяки відносній автономності і співвіднесеності слова 3 позамовним світом, воно відіграє величезну пізнавальну роль у мисленні і комунікації, саме тому позиція лінгвістів, які обмежують роль слова лише функційною, $є$ не зовсім виправданою.

Більшість прихильників «формально-функційного» погляду на значення слова обгрунтовують свої теоретичні положення на тій підставі, що самостійно, поза реченням слова не живуть реальним життям, вони $€$ мовними знаками-номінаціями, переважно глибоко конвенційно пов'язаними 3 позначуваними об'єктами. За словами О. Авоян, «назви самі не висловлюють і не описують, вони лише вказують на певні 
позалінгвальні об’єкти. Вони «вводять» речі в речення, надаючи їм тим самим можливість говорити про них щось засобами речення» [1, с. 71]. Безперечно, світ речей у кінцевому підсумку визначає усвідомлення наших мовних виражень, у цьому плані референційна теорія значення отримує своє підтвердження. Проте зв'язок навколишнього світу з мовою не $\epsilon$ таким простим, як вона ії представляє. За справедливим зауваженням В. Олстона, «мова складається не лише з ряду етикеток, кожна 3 яких пов'язана із чимось у «світі» [9, с. 19], тому значення речень не можна звести лише до референційного зв'язку його окремих компонентів із позамовними об'єктами. Покликатися на об'єкти - це хоча й важлива, але далеко не єдина функція мови. Значення речення висловлює, скоріше, людські відношення до речей, тобто воно несе у собі щось значно більше, аніж зв'язок його окремих компонентів із фрагментами дійсності.

Безперечно, лексична семантика мови репрезентує екстралінгвіальні факти - речі, якості, відношення, події тощо, і застосування до неї терміна «відображення» має сенс. Але «відображення» у гносеологічному плані як динамічний процес відтворення дійсності в людській свідомості сформований у результаті цілеспрямованої діяльності людини, зокрема мовної діяльності. Про відображення як процес можна говорити на рівні мовленнєвої діяльності, але мовленнєва діяльність - це щось значно більше, аніж мовна система. Мова - це не лише словник, але й також принципи і засоби організації мовлення, тому саме дія, актуальне застосування i перетворює мову на засіб відображення. Лексична семантика - це, швидше, необхідна основа для відображення. Спонукаючи мову до дії, людина стверджує щось про явища навколишньої дійсності, водночас виражаючи своє ставлення (оцінку) до них. Саме в цьому процесі мова виступає як засіб відображення дійсності, саме тут мовна творчість виступає у тісному взаємозв'язку 3 перебігом думки, яка створює динамічну пізнавальну картину світу. Результати відображення дійсності, що акумульовані у лексичній семантиці, збагачують мову як інструмент пізнання і сприяють тим самим подальшому, повнішому відображенню іiі людським мисленням.

Мовознавство протягом тривалої історії свого розвитку переживало різні і часто полярні періоди ставлення своїх представників до значеннєвих аспектів мови загалом і лексичної семантики зокрема. Донедавна у східнослов'янському мовознавстві ігнорували багато засадничих питань значеннєвої організації мовної системи, увага дослідників була зосереджена на питаннях формальних засобів мови, вибудови ії системи. Цей етап змінився за кілька останніх десятиліть новим, протилежним, який ๑ О. О. І. Леута, 2015. 
називають «вибухом семасіології у лінгвістиці». Семантичні дослідження одиниць різних рівнів мови та аспектів розгляду сприяли виробленню відповідної термінології 3 диференціацією семантики: лексичної, синтаксичної, морфологічної, словотвірної, прагматичної, контекстної, породжувальної тощо. Таке широке коло семантичних аспектів зумовлене не лише вибором різних об'єктів аналізу, але й метою, завданнями, методами, шляхами дослідження.

У минулому столітті у східнослов'янському мовознавстві остаточно сформувалося розуміння слова як двосторонньої одиниці, що характерна показниками виділюваності, цільнооформленості, семантичної і формальної цілісності, ідіоматичності лексичного значення. Становлення такої позиції поставило на порядку денному актуальне, складне і до цього часу лише частково розв'язане питання дослідження семантики мовних одиниць. Пильна увага мовознавців до цього основоположного питання зумовила необхідність розв'язання багатьох дотичних і часткових проблем, як-от: учені перестали обмежуватися визначенням лексичного значення лише за референтом без урахування мовних засобів його вираження; сформувалася і стала домінантною тенденція системного дослідження компонентів змісту слова; було закладено основи контекстологічного опису семантики слова, а також сформульовано поняття семантичної структури слова i лексикосемантичної системи мови.

Хоч цілісний аналіз сукупності семантичних відношень у лексиці, на перший погляд, видається неможливим із-за невичерпності словникового складу мови на кожному етапі iї розвитку, відносно цілісний аналіз може бути здійснений шляхом об'єднання значень під узагальненими категорійними поняттєвими структурами. Так, аналізуючи формування основних категорій розуміння зв'язків людини із навколишнім світом, А. Шептулін виділяє головними 3 них такі: буття, простір, час, рух, відмежування (відчленування), якість, кількість, відношення [8, с.174]. Категорії діалектики сприяють усвідомленню значення певного слова, його ролі у процесі пізнання, підведенню того чи того значення під загальніше родове поняття, адже пошук варіантів системи категорій пізнання іде паралельно з постійною багатомірною класифікацією лексичного матеріалу, 3 прагненням досягти хоч би приблизного його всеохоплення.

Можна припустити, що ці виділені 8 категорій пізнання є першим гносеологічним параметром загальної концептуальної схеми моделі семантичних відношень у лексиці. Категорії пізнання, які $\epsilon$ за своєю 
природою надзвичайно широкими, фундаментальними поняттями, відображають не тільки істотні ознаки предметів і явищ, але й відображають зв'язки та відношення між ними.

Очевидно, що на відміну від фонетики і граматики, описати лексичний склад мови, який нараховує сотні тисяч слів, набагато важче. Тому в лексиці у зв'язку з необчисленістю їі одиниць (вокабул) встановити системність видається дуже складним чи навіть нерозв'язним питанням.

\section{Література}

1. Авоян О. Г. Значение в языке : Философский анализ / О. Г. Авоян. - М. : Высшая школа, 1985. - $103 \mathrm{c.}$

2. Балли Ш. Общая лингвистика и вопросы французского языка / Ш. Балли : [пер. с франц.]. - М. : Изд-во иностр. лит., 1955. - 416 с.

3. Виноградов В. В. Русский язык : Грамматическое учение о слове / В. В. Виноградов. - М. : Высшая школа, 1986. -640 с.

4. Вихованець I. Р. Граматика української мови. Синтаксис / I. Р. Вихованець. К. : Либідь, 1993. -368 с.

5. Звегинцев В. А. Теоретическая и прикладная лингвистика / В. А. Звегинцев. М. : Просвещение, 1968. -336 с.

6. Кондаков Н. И. Логический словарь-справочник / Н. И. Кондаков. - [изд. 2-е]. - М. : Наука, 1975. - 720 c.

7. Смирницкий А. И. Лексическое и грамматическое в слове / А. И. Смирницкий // Вопросы грамматического строя. - М. : АН СССР, 1955. - С. 11-53.

8. Шептулин А. П. Система категорий диалектики / А. П. Шептулин. - М. : Наука, 1967. $-288 \mathrm{c}$.

9. Alston W. Philosophy of Language / W. Alston. - N.Y. : Prentice-Hall, 1964. - 113 p.

10. Church J. Language and the Discovery of Reality / J. Church. - N.Y. : Random House, Inc., $-1961 .-245$ p.

Стаття надійшла до редакиії 29.08.2015 p. 